\title{
Effect of milk replacer feeding rate and functional fatty acids on dairy calf performance and digestion of nutrients
}

\author{
T. M. Hill, ${ }^{1}$ J. D. Quigley, F. X. Suarez-Mena, H. G. Bateman II, ${ }^{2}$ and R. L. Schlotterbeck \\ Nutrition and Research Center, Provimi, 10 Nutrition Way, Brookville, $\mathrm{OH} 45309$
}

\begin{abstract}
Calves fed large amounts of milk replacer (MR) gain more body weight preweaning than calves fed less MR; however, postweaning growth may be reduced because of impaired digestion of nutrients. This was explored in the current research, as was the inclusion of functional fatty acids (NT) that could ameliorate some poor growth and digestion issues in calves fed large amounts of MR. Two MR rates [moderate (MOD) or aggressive (AGG)] with and without NT were compared using 48 male Holstein calves initially $3 \mathrm{~d}$ old $(43 \pm 1.5 \mathrm{~kg}$ of body weight) randomly assigned to treatments. The MOD rate was fed at $0.66 \mathrm{~kg}$ of dry matter (DM) for $49 \mathrm{~d}$. The AGG rate was fed for $4 \mathrm{~d}$ at $0.66 \mathrm{~kg}$ of DM, $4 \mathrm{~d}$ at $0.96 \mathrm{~kg}$ of DM, then $34 \mathrm{~d}$ at $1.31 \mathrm{~kg}$ of DM, followed by $0.66 \mathrm{~kg}$ of DM for the last $7 \mathrm{~d}$. Calves were completely weaned at $49 \mathrm{~d}$. The MR contained $27 \%$ crude protein and $17 \%$ fat. The textured starter was $20 \%$ crude protein. Starter and water were fed free-choice for the first $56 \mathrm{~d}$ when calves were housed in individual pens. From 56 to 112 d, calves were grouped (4 calves/pen), maintaining the same MR rate and NT treatments, and fed starter blended with 5\% chopped grass hay free-choice with free-choice water. Digestibility was estimated from fecal collections made on d 19 to 23,40 to 44 , and 52 to 56 . Data were analyzed as a completely randomized design with a factorial arrangement of MR rate and NT using repeated measures with a mixed procedure. Fiber and starch digestion increased with age and was lower for AGG versus MOD. Calf average daily gain and hip width change were greater before approximately $6 \mathrm{wk}$ of age for AGG versus MOD, but this was reversed from approximately 6 to 16 wk. Calves fed AGG had lower average daily gain per unit intake of DM, crude protein, and metabolizable energy from 8 to 16 wk than calves fed MOD. Preweaning starter intake was less for calves fed AGG versus MOD. Calves fed AGG had
\end{abstract}

Received December 23, 2015.

Accepted May 8, 2016.

${ }^{1}$ Corresponding author: mhill@provimi-na.com

${ }^{2}$ Deceased. greater body weight gain than MOD over $112 \mathrm{~d}$, but hip width change did not differ. Feeding NT improved digestibility of organic matter, DM, neutral detergent fiber, and acid detergent fiber (over 50\% improvement for neutral detergent fiber and acid detergent fiber), which resulted in $10.7 \mathrm{~kg}(13 \%)$ more body weight gain and $1.4 \mathrm{~cm}(16 \%)$ more hip width change over $112 \mathrm{~d}$. This was a greater improvement in growth than the difference in AGG and MOD programs over $112 \mathrm{~d}$.

Key words: calf, milk replacer, digestion

\section{INTRODUCTION}

As milk more milk or milk replacer (MR) has been fed to calves, preweaning ADG has increased and preweaning starter intake has decreased (Jasper and Weary, 2002; Cowles et al., 2006; Hill et al., 2013). However, when the DM fed from liquid has exceeded approximately $0.7 \mathrm{~kg}$ of $\mathrm{DM}$ and weaning has taken place over approximately a week or less, postweaning ADG was less than when less liquid was fed (Cowles et al., 2006; Hill et al., 2007c, 2013). The lower postweaning ADG appears to largely be the result of lower digestion of OM and NDF by calves fed greater amounts of MR (Terre et al., 2007a,b; Hill et al., 2010) and less a function of postweaning DMI. The low digestibility in calves fed high levels of MR has been associated with less development of the rumen (Terre et al., 2007a,b; Suarez-Mena et al., 2011). Preweaning MR intake has not influenced DMI after $56 \mathrm{~d}$ when expressed as grams per day; however, intake has been less after $56 \mathrm{~d}$ when expressed as DM per kilograms of BW when the MR program delivered more than approximately $0.7 \mathrm{~kg}$ of DM daily (Hill et al., 2010, 2013; Osorio et al., 2012). Postweaning feed efficiency has been poor in calves fed high versus low amounts of MR, beyond the immediate few days postweaning (Hill et al., 2007c, 2010). This suggests that digestion is compromised for at least a few weeks postweaning.

Starter intake and the fermentation of starch in the rumen develops the rumen (Hibbs et al., 1956; Warner et al., 1956), drives ADG in the first 2 mo of a calf's life (Heinrichs and Heinrichs, 2011; Bateman et al., 2012), 
and has been associated with more milk, fat, and protein production in first lactation and throughout life (Heinrichs and Heinrichs, 2011). Thus, feeding more milk or MR can reduce starter intake and slow rumen development, often reducing growth of calves in the late preweaning and early postweaning period (Terre et al., 2007a,b; Hill et al., 2010).

There is more to providing nutrients to calves than simply amount of MR, energy, or CP. A balance of AA (Hill et al., 2007b, 2008) and fatty acids (Hill et al., 2011; Kato et al., 2011; Esselburn et al., 2013) have been reported to optimize growth and health of calves, and many MR in the United States lack specific fatty acids (i.e., butyric and linolenic acids) for optimum growth and health of calves. Butyric and linolenic acid are functional in the immune and digestive systems (Hill et al., 2011; Esselburn et al., 2013). Butyric acid stimulates the maturation of pancreatic enzymes (Guilloteau et al., 2009; Górka et al., 2011; Kato et al., 2011) and rumen papillae, both digestive components that may be delayed in calves fed large amounts of milk or MR.

More information is needed to understand how MR rate alters digestion with age in calves. For that reason, we evaluated $2 \mathrm{MR}$ feeding rates on calf performance, as well as pre- and postweaning digestion of several nutrients. Additionally, functional fatty acids that are missing in typical MR and that influence the digestive development of the calf were evaluated. Our hypothesis was that pre- and early postweaning digestion of nutrients would be less in calves fed more MR and that specific functional nutrients could increase digestive maturation.

\section{MATERIALS AND METHODS}

All animals were cared for as described in the Guide for the Care and Use of Agricultural Animals in Research and Teaching (FASS, 2010). This trial began with a 56-d nursery phase where calves were housed in individually pens. Two MR rates [moderate (MOD) or aggressive (AGG)] with and without functional nutrients of NeoTec5g (NT; Provimi, Brookville, $\mathrm{OH}$ ) were compared using 48 calves (12/treatment; $43 \pm 1.5 \mathrm{~kg}$ of BW) randomly assigned to treatments. NeoTec5g contains a specific blend of functional fatty acids that are primarily butyric, lauric, myristic, and linolenic acid. These fatty acids have been shown to have function in the immune and digestive systems and for growth in calves, and are typically in low concentrations of the diets fed to calves (Hill et al., 2009a, 2011; Kato et al., 2011). The MOD rate of MR was fed at $0.66 \mathrm{~kg}$ of DM for $49 \mathrm{~d}$. The AGG rate of MR was fed for $4 \mathrm{~d}$ at
$0.66 \mathrm{~kg}$ of DM, $4 \mathrm{~d}$ at $0.96 \mathrm{~kg}$ of DM, then $34 \mathrm{~d}$ at 1.31 $\mathrm{kg}$ of DM, followed by $0.66 \mathrm{~kg}$ of DM for the last $7 \mathrm{~d}$. The MR feedings were divided into 2 equal morning and evening meals. The MOD rate was reconstituted to $13 \%$ solids. The AGG rate was reconstituted to $15 \%$ solids for the first $42 \mathrm{~d}$, then $13 \%$ solids for the last $7 \mathrm{~d}$. All calves were fed the same the last $7 \mathrm{~d}(0.66$ $\mathrm{kg}$ of $\mathrm{DM}$ from $\mathrm{MR}$ in a $13 \%$ solution, divided into 2 equal meals daily d 41 to 49 and no MR was fed on d 50 and after) to minimize any effect that liquid feeding method would have on calves postweaning to better evaluate the amount of MR fed. The MR powder had $27 \% \mathrm{CP}$ and $17 \%$ fat from whey, whey protein concentrate, lard, minerals, and vitamins. Calves were fed a $20 \%$ CP textured starter, composed of $37 \%$ whole corn, 35\% supplement pellet (soybean meal, wheat middlings, minerals, and vitamins), $25 \%$ whole oats, and $3 \%$ liquid molasses. A premix with the fatty acids for NT was included in the designed MR and starters. Calves were fed the starter and water ad libitum for the 56-d trial. During the first $49 \mathrm{~d}$, the starter fed to all calves did not contain NT. For last $7 \mathrm{~d}$ of the nursery phase, a second similar starter with NT was fed to calves previously receiving NT via the MR whereas other calves continued on the starter without NT. The MR were formulated to contain $0.25 \%$ chromic oxide (as-fed basis). The basis was to achieve an intake of approximately $2 \mathrm{~g}$ or more of chromic oxide per calf daily, exceeding the minimum suggested $1 \mathrm{~g} /$ calf daily for digestibility estimates (Bouchard et al., 1973).

From 56 to 112 d, a grower phase was conducted with the same calves grouped (4 per pen) based on the 4 nursery phase treatments. The same starters with and without NT were fed blended with $5 \%$ chopped grass hay. This allowed the continuation of the factorial arrangement of $2 \mathrm{MR}$ rate (previously fed) and 2 starters (with and without NT). The analyses of MR, starters, and hay are reported in Table 1.

Calves were 2 to $4 \mathrm{~d}$ of age at the beginning of the trial and came from a single dairy farm. According to the farm's protocol, these calves were fed $3 \mathrm{~L}$ of maternal colostrum at birth and again approximately $12 \mathrm{~h}$ after birth. Calves were received at midday after a 3.5 -h transit and at the evening feeding calves were randomly assigned to experimental programs. The day after arrival, at approximately noon, the calves were weighed (d 0, initial BW), and blood was collected from the jugular vein. Serum was separated by centrifugation at $3,000 \times g$ at $20^{\circ} \mathrm{C}$ for $15 \mathrm{~min}$ (VWR, Batavia, IL) and serum protein concentration was estimated using an optical refractometer (ATAGO U.S.A. Inc., Bellevue, WA). Fecal grab samples were taken from the same 5 calves randomly selected per treatment on d 19 to 23 , 
40 to 44 , and 52 to 56 , frozen daily, combined on an equal wet weight basis, and subsampled for analysis. Twelve fecal grab samples per calf were taken via rectal palpation by hand to account for 2-h intervals (0200, 0400, $0600 \mathrm{~h}$, and so on) of the 24-h day by rotating sampling times over the 5-d collection period.

In the first 56-d nursery phase, calves were weighed initially and every $7 \mathrm{~d}$. Hip widths of the calves were measured with a caliper and BCS was estimated initially and every $14 \mathrm{~d}$. Calf BCS was based on a 1-to- 5 system using 0.25-unit increments, with 1 being emaciated and 5 being obese (Wildman et al., 1982). Scores were based on changes around the vertical and transverse processes of the spine as palpated by an experienced technician. Starter intake offered and refused was measured daily. Feces were scored daily in the first $56 \mathrm{~d}$ (1-to- 5 scale modified from Kertz and Chester-Jones, 2004). In the grower phase from 56 to 112 d, calves were weighed, measured for hip width, and scored for BCS on d 84 and 112. Feed and water were offered free-choice and were available at all times; refused feed was measured daily.

In the nursery phase (first $56 \mathrm{~d}$ ) calves were housed individually in $1.2-$ by $2.4-\mathrm{m}$ pens bedded with straw in a curtain-sided, naturally ventilated barn with no added heat. From d 56 to 112, calves were housed in group pens ( 4 calves/pen) with $6.5 \mathrm{~m}^{2}$ of outside pen space and $1.35 \mathrm{~m}^{2}$ of inside pen space per calf. Calves were grouped by previous MR treatment, randomly assigned before the previous 56-d period, at time of initial randomization. The inside pen space was bedded with straw and there was no added heat. The trial was conducted July through October. The average temperature in the nursery was $21^{\circ} \mathrm{C}$ with a range from 5 to $35^{\circ} \mathrm{C}$. The average relative humidity was $77 \%$ with a range from 32 to $98 \%$.

Composites of feed and fecal samples were analyzed (AOAC International, 2000) for DM (oven method 930.15), CP (Kjeldahl method 988.05), fat (alkaline treatment with Roese-Gottlieb method 932.06 for MR; diethyl ether extraction method 2003.05 for starters and hay), fatty acids (feed only, GC; method 963.22), starch ( $\alpha$-amylase method; Hall, 2009), and sugar (Dubois et al., 1956). The starter and feces were analyzed for NDF with ash by the procedure of Van Soest et al. (1991) without sodium sulfite or $\alpha$-amylase, and ADF with ash (Robertson and Van Soest, 1981). The MR and feces from the 2 preweaning collection times were analyzed for $\mathrm{Cr}$ (AOAC International, 2000; method 993.14). Feeds and fecal samples during the postweaning period were analyzed for acid-insoluble ash (Van Keulen and Young, 1977). Measured concentrations of

Table 1. Analyzed nutrients in feeds

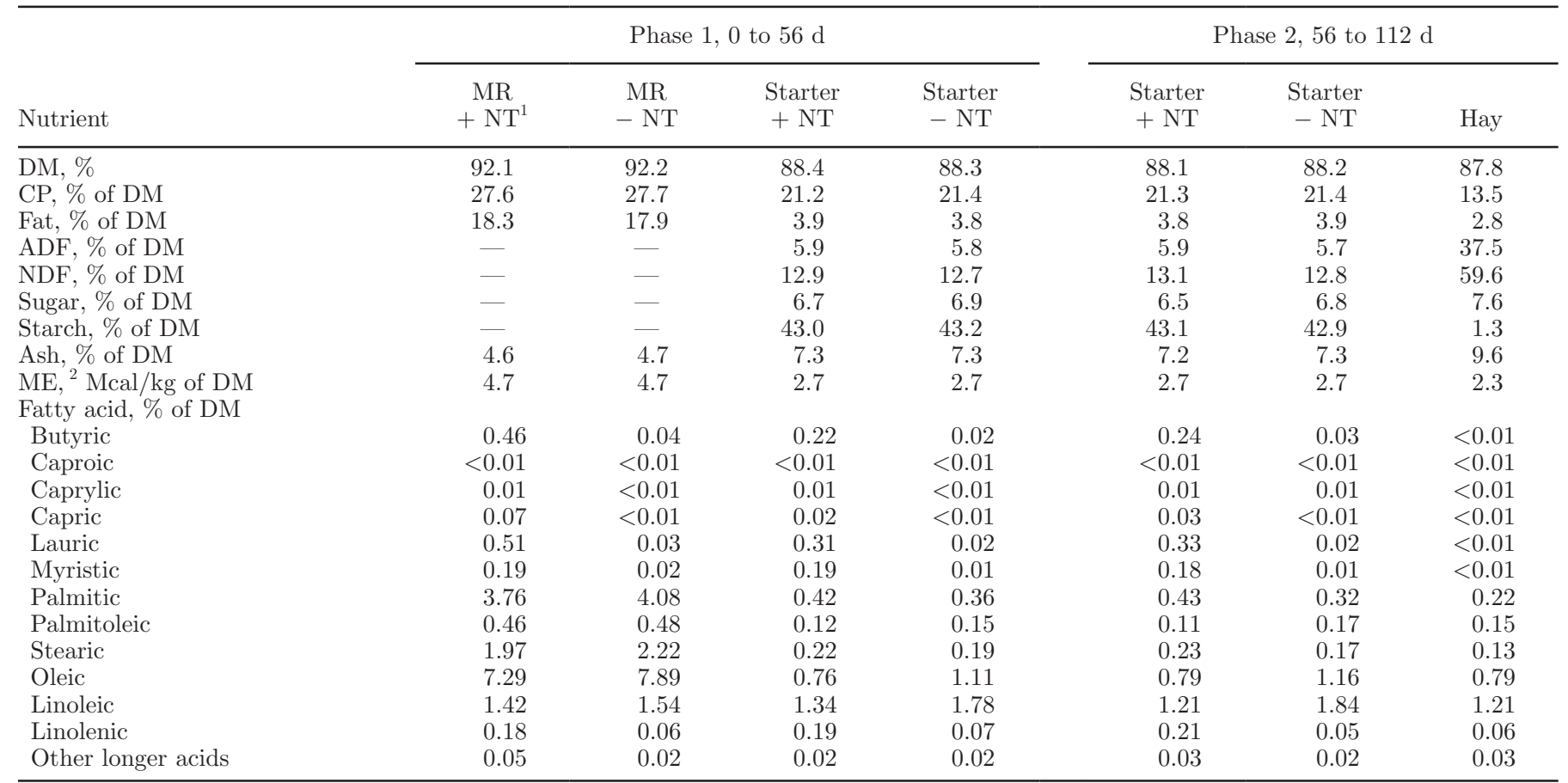

${ }^{1}$ Milk replacer (MR) and functional fatty acids (NT).

${ }^{2}$ Calculated using NRC (2001). 
Cr or acid-insoluble ash and other nutrients in the feed, feed intake, and $\mathrm{Cr}$ or acid-insoluble ash and other nutrient concentrations in the feces were used to estimate fecal output and apparent digestibility.

Statistical analyses were conducted for the first 56-d period when calves were penned individually and again separately for the d 56 to 112 when calves were grouped in pens of 4 calves. Data for the first $56 \mathrm{~d}$ were summarized by week for all data, except hip widths and BCS that were summarized by $14 \mathrm{~d}$. Data for d 56 to 112 were summarized by $28 \mathrm{~d}$. Data were analyzed as a completely randomized design, using repeated measures over time by Proc Mixed in SAS (version 8, SAS Institute, Inc., Cary, NC) in a 2 by 2 factorial arrangement of MR rate (MOD and AGG) by NT (with and without NT). Significance was declared when $P<0.05$. Pen was the experimental unit. Initial BW differed in the analysis, so initial BW was added to the model as a covariate. The covariate analysis did not change the differences among treatments or improve the model; thus, the model without covariate analyses was used.

\section{RESULTS}

Initial serum protein was lower $(P=0.04)$ for calves fed NT versus not fed NT (Table 2). We found no interactions of the main effects. Week interacted with $\mathrm{MR}$ rate for $\mathrm{ADG}$, hip width change (HWC), and starter intake $(P<0.01 ;$ Figure 1$)$. For all performance measurements, week was significant $(P<0.05)$. Calves fed AGG had greater $(P<0.05)$ ADG, BCS change, and average fecal score compared with calves fed MOD. Calves fed NT had greater $(P<0.03)$ ADG and HWC compared with calves not fed NT.

Total intake in units per day of DM, CP, fat, and ME were greater $(P<0.02)$ for calves fed AGG versus MOD (Table 3). Intake per unit BW of CP, fat, and ME were greater $(P<0.05)$ for calves fed AGG versus MOD. Intake of nutrients did not differ by NT. Efficiency of $\mathrm{CP}$ and ME use (grams of ADG per grams of $\mathrm{CP}$ intake or megacalories of ME intake) was not different among treatments.

The interaction of NT by MR rate by period was significant $(P<0.03)$ for most nutrients measured (Table 4). We noted no interaction of NT by MR rate; however, rate by period did interact $(P<0.05)$. Digestibility of DM, OM, NDF, and ADF was greater $(P$ $<0.05$ ) for calves fed NT versus not fed NT for each digestibility measurement period (Tables 5, 6, and 7) and overall (Table 4).

From d 19 to 23, digestibility of CP, DM, and OM was greater $(P<0.003)$ in calves fed AGG versus MOD (Table 4). From d 40 to 44 , digestibility of fat, DM, and $\mathrm{OM}$ was greater $(P<0.05)$ in calves fed AGG versus MOD. From d 52 to 56 , digestibility of fat, DM, and $\mathrm{OM}$ was less $(P<0.05)$ in calves fed AGG versus

Table 2. Performance of calves fed 2 milk replacer (MR) rates ${ }^{1}$ with and without functional fatty acids (NT) during the 0 - to 56 -d nursery phase

\begin{tabular}{|c|c|c|c|c|c|c|c|c|}
\hline \multirow[b]{2}{*}{ Item } & \multicolumn{2}{|c|}{ With NT } & \multicolumn{2}{|c|}{ Without NT } & \multirow[b]{2}{*}{ SEM } & \multicolumn{3}{|c|}{$P$-value } \\
\hline & MOD & AGG & MOD & AGG & & NT & Rate & $\mathrm{NT} \times$ rate \\
\hline Initial serum protein, $\mathrm{mg} / \mathrm{dL}$ & 5.1 & 5.3 & 5.4 & 5.6 & 0.14 & 0.04 & 0.21 & 0.81 \\
\hline Initial BW, kg & 41.6 & 46.5 & 38.6 & 43.8 & 1.50 & 0.07 & 0.001 & 0.93 \\
\hline Final BW, kg & 74.3 & 89.6 & 67.5 & 83.9 & 2.06 & 0.001 & 0.001 & 0.79 \\
\hline Initial hip width, $\mathrm{cm}$ & 17.5 & 18.6 & 17.3 & 18.1 & 0.31 & 0.24 & 0.003 & 0.76 \\
\hline Final BCS & 2.5 & 2.6 & 2.5 & 2.6 & 0.03 & 0.11 & 0.001 & 0.86 \\
\hline MR intake, $\mathrm{kg} / \mathrm{d}$ & 0.578 & 1.044 & 0.578 & 1.044 & - & - & - & - \\
\hline Starter intake, $\mathrm{kg} / \mathrm{d}$ & 0.628 & 0.413 & 0.496 & 0.410 & 0.0501 & 0.19 & 0.004 & 0.21 \\
\hline $\mathrm{ADG}, \mathrm{kg} / \mathrm{d}$ & 0.584 & 0.770 & 0.515 & 0.716 & 0.0282 & 0.03 & 0.001 & 0.79 \\
\hline Feed efficiency ${ }^{2}$ & 0.487 & 0.532 & 0.473 & 0.479 & 0.0216 & 0.13 & 0.24 & 0.37 \\
\hline Hip width change, $\mathrm{cm}$ & 5.3 & 5.6 & 4.3 & 4.7 & 0.25 & 0.001 & 0.14 & 0.90 \\
\hline BCS change ${ }^{3}$ & 0.3 & 0.4 & 0.3 & 0.4 & 0.07 & 0.12 & 0.001 & 0.81 \\
\hline
\end{tabular}

${ }^{1}$ Moderate (MOD): $0.66 \mathrm{~kg}$ of DM of a $27 \% \mathrm{CP}, 17 \%$ fat MR powder daily fed for $49 \mathrm{~d}$; aggressive (AGG): $0.66 \mathrm{~kg}$ of DM of a $27 \% \mathrm{CP}, 17 \%$ fat MR powder fed for $4 \mathrm{~d}$, then $0.96 \mathrm{~kg}$ of DM for $4 \mathrm{~d}$, then $1.31 \mathrm{~kg}$ of DM fed for $34 \mathrm{~d}$, then $0.66 \mathrm{~kg}$ of DM for $7 \mathrm{~d}$.

${ }^{2}$ Feed efficiency was calculated as gain divided by the sum of MR and starter intake.

${ }^{3} 1$ - to 5 -point system, with 1 being thin and 5 being obese.

${ }^{4}$ Feces were scored daily using a 1 - to 5 -scale, with 1 being normal and 5 being watery.

${ }^{5}$ Days with fecal scores of 3 or greater. 
Table 3. Dry matter and nutrient intake of calves fed 2 milk replacer (MR) rates ${ }^{1}$ with and without functional nutrients (NT) during the 0 to 56-d nursery phase

\begin{tabular}{|c|c|c|c|c|c|c|c|c|}
\hline \multirow[b]{2}{*}{ Item } & \multicolumn{2}{|c|}{ With NT } & \multicolumn{2}{|c|}{ Without NT } & \multirow[b]{2}{*}{ SEM } & \multicolumn{3}{|c|}{$P$-value } \\
\hline & MOD & AGG & MOD & AGG & & NT & Rate & $\mathrm{NT} \times$ rate \\
\hline Fat intake, $\mathrm{kg} / \mathrm{d}$ & 0.13 & 0.20 & 0.12 & 0.20 & 0.016 & 0.35 & 0.01 & 0.28 \\
\hline ME intake, ${ }^{2} \mathrm{Mcal} / \mathrm{d}$ & 4.41 & 6.02 & 4.06 & 6.01 & 0.052 & 0.31 & 0.01 & 0.34 \\
\hline $\mathrm{g}$ of $\mathrm{ADG} / \mathrm{g}$ of $\mathrm{CP}$ intake & 1.99 & 2.04 & 1.94 & 1.90 & 0.098 & 0.32 & 0.24 & 0.31 \\
\hline $\mathrm{CP}$ intake, $\mathrm{g} / \mathrm{kg}$ of $\mathrm{BW}$ & 5.1 & 5.5 & 5.0 & 5.9 & 0.25 & 0.19 & 0.05 & 0.26 \\
\hline Fat intake, $\mathrm{g} / \mathrm{kg}$ of $\mathrm{BW}$ & 2.2 & 3.0 & 2.3 & 3.2 & 0.12 & 0.34 & 0.02 & 0.39 \\
\hline $\mathrm{ME}$ intake, ${ }^{2} \mathrm{kcal} / \mathrm{kg}$ of $\mathrm{BW}$ & 76.1 & 88.5 & 76.5 & 94.2 & 4.17 & 0.18 & 0.01 & 0.32 \\
\hline
\end{tabular}

${ }^{1}$ Moderate (MOD): $0.66 \mathrm{~kg}$ of DM of a $27 \% \mathrm{CP}, 17 \%$ fat MR powder daily fed for $49 \mathrm{~d}$; aggressive (AGG): $0.66 \mathrm{~kg}$ of DM of a $27 \% \mathrm{CP}, 17 \%$ fat MR powder fed for $4 \mathrm{~d}$, then $0.96 \mathrm{~kg}$ of DM for $4 \mathrm{~d}$, then $1.31 \mathrm{~kg}$ of DM fed for $34 \mathrm{~d}$, then $0.66 \mathrm{~kg}$ of DM for $7 \mathrm{~d}$.

${ }^{2}$ Calculated using NRC (2001).

MOD. Preweaning (d 19 to 23, 40 to 44) digestibility of starch was less $(P<0.001)$ in calves fed AGG versus MOD. For each digestibility measurement period and overall, digestibility of $\mathrm{ADF}$ and $\mathrm{NDF}$ were less $(P<$ 0.04) in calves fed AGG versus MOD.

From 56 to $84 \mathrm{~d}$, calves fed NT had greater $(P<$ $0.02)$ ADG and HWC than calves not fed NT (Table 8). Additionally, calves fed NT had a greater $(P=0.04)$ DMI as kilograms per day than calves not fed NT; however, DMI did not change when expressed per unit BW. Calves previously fed AGG had a lower $(P<0.02)$ feed efficiency, HWC, and BCS change than calves fed MOD. Calves previously fed AGG tended $(P<0.08)$ to have a lower ADG than calves fed MOD.
Total BW gain from 0 to $112 \mathrm{~d}$ was $97.1,105.8,86.5$, and $95.0 \mathrm{~kg}$ for calves fed NT-MOD, NT-AGG, MOD, and AGG, respectively. Total HWC from 0 to $112 \mathrm{~d}$ was $11.3,10.5,9.4$, and $9.3 \mathrm{~cm}$ for calves fed NT-MOD, NTAGG, MOD, and AGG, respectively. Statistics were not performed on these means because the experimental unit changed between the nursery and grower phases.

\section{DISCUSSION}

Postweaning digestibility measurements in our trial were consistent with measurements previously reported (Terre et al., 2007a,b; Hill et al., 2010) where digestibility was less with higher versus lower MR feeding

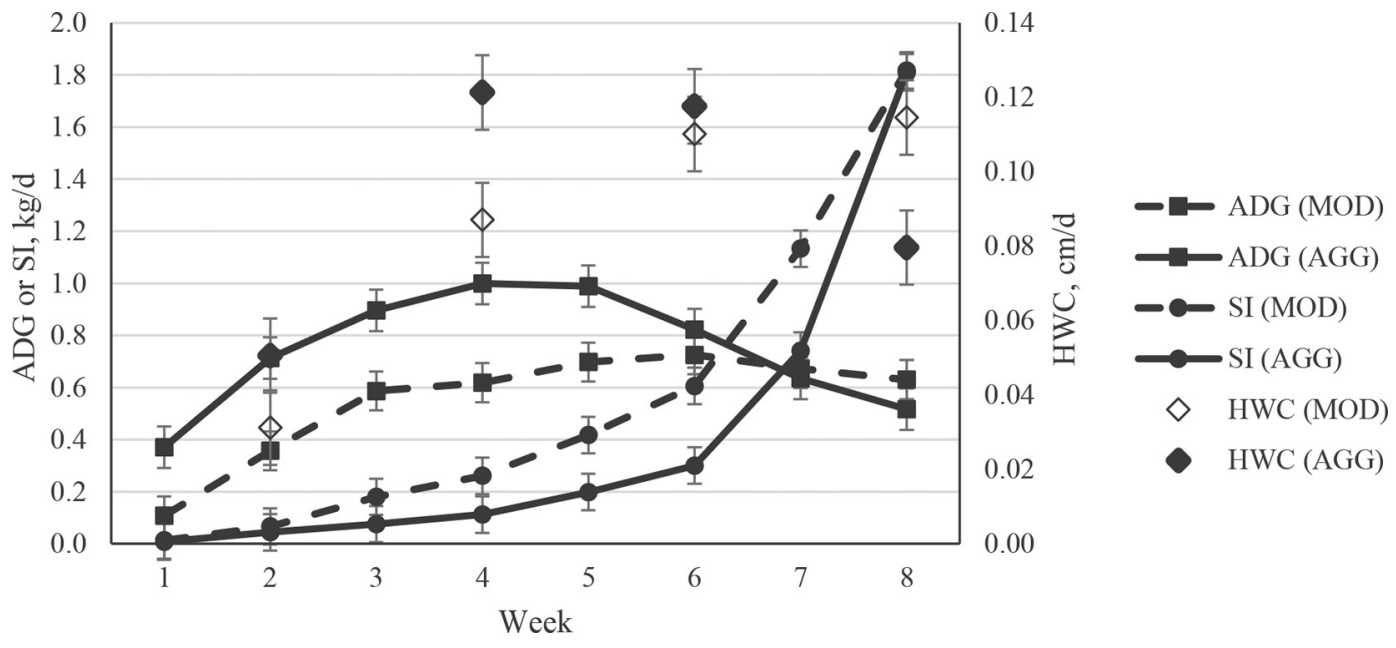

Figure 1. Average daily gain, starter intake (SI), and hip width change (HWC) for calves fed moderate (MOD) and aggressive (AGG) milk replacer (MR) programs over 8 wk of the nursery phase. The main effect of functional nutrient is averaged into MR programs; ADG differed for wk 2 through $5(P<0.01)$, SI differed for wk 4 through $7(P<0.01)$, HWC differed for wk 2,4 , and $8(P<0.01$. $)$ MOD $=0.66 \mathrm{~kg}$ of DM of a $27 \% \mathrm{CP}, 17 \%$ fat MR powder daily fed for $49 \mathrm{~d}$; AGG $=0.66 \mathrm{~kg}$ of DM of a $27 \% \mathrm{CP}, 17 \%$ fat MR powder fed for $4 \mathrm{~d}$, then $0.96 \mathrm{~kg}$ of DM for $4 \mathrm{~d}$, then $1.31 \mathrm{~kg}$ of DM fed for $34 \mathrm{~d}$, then $0.66 \mathrm{~kg}$ of DM for $7 \mathrm{~d}$. 


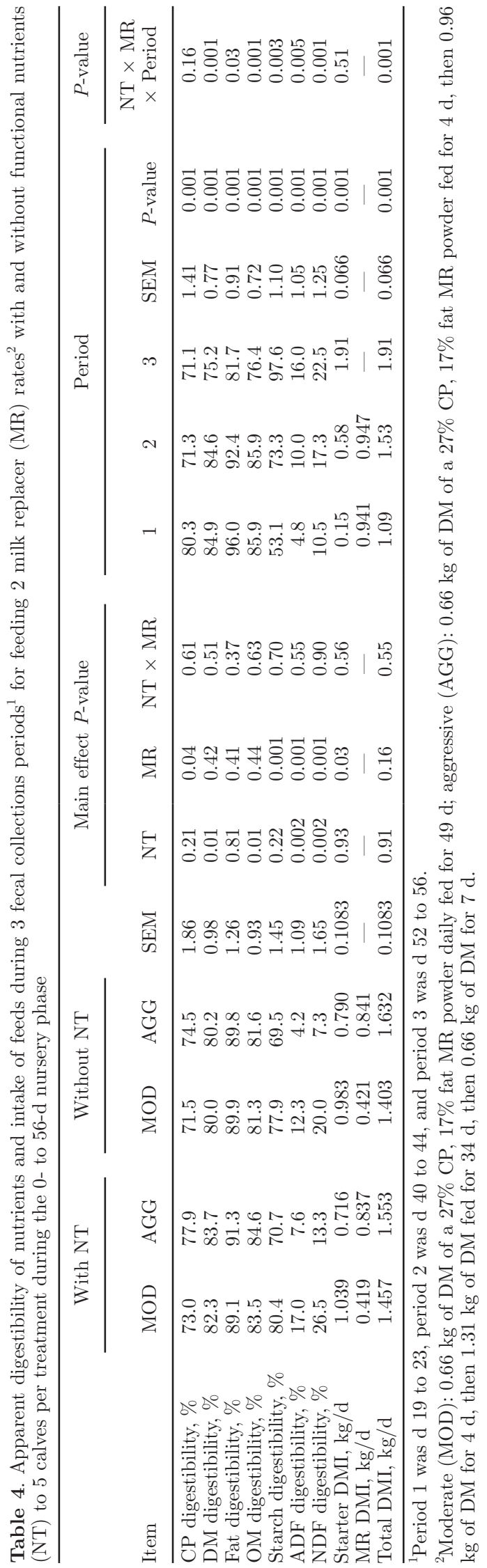

rates. Additionally, the difference in NDF digestibility during the postweaning period between MR rates was large, as previously reported (Terre et al., 2007a,b; Hill et al., 2010). These OM and NDF digestibility values obtained in postweaned calves of approximately 2 mo of age are lower than that reported in lactating cows fed typical mixed corn and forage diets (Bernard et al., 1991) and feedlot steers fed high-corn, low-forage diets (Sayer et al., 2013).

Preweaning digestibility of NDF and ADF was much lower than postweaning digestibility in the current trial and previously reported (Terre et al., 2007a,b; Hill et al., 2010), indicating that the rumen was developing. Additionally, NDF and ADF digestibility was lower in calves fed AGG versus MOD, indicating that rumen development was less in AGG versus MOD calves. Starch digestion was lower in calves fed AGG versus MOD preweaning, plus digestibility of starch increased with age, further evidence for rumen development increasing with age. Starch is fermented by microbes in both the rumen and large intestine and digested by mammalian enzymes in the small intestine of calves and should be easier to digest than NDF and ADF (NRC, 2001), as indicated by greater digestibility coefficients of starch versus NDF and ADF. The starch digestion results reflect AGG slowing rumen and pancreatic development of calves compared with MOD.

Whereas calves fed AGG had greater ADG and HWC in the first 4 to 5 wk of age (Figure 1), this was not true thereafter. During d 52 to 56, digestion of many nutrients were less for AGG versus MOD. With lower efficiency of nutrient use for ADG from d 56 to 112, it could be assumed that digestion of nutrients were also lower for calves fed AGG versus MOD. A lower feed efficiency and digestion of nutrients combined with more ADG, and less HWC and BCS change could reflect more gut fill and gut mass gain in calves fed AGG versus MOD, yet gut fill would not influence HWC.

Others have reported similar BW gain from birth until 3 or 4 mo of age between calves fed AGG and MOD (Hill et al., 2007c, 2010, 2013), whereas here the BW gain of AGG calves was greater than MOD calves at $112 \mathrm{~d}$. A difference between the findings could be the weaning programs implemented. In the current trial, calves fed both MOD and AGG were fed the same amount of MR during wk 7 (final week of the preweaning phase) and weaned on d 49, which was intentional in the design to bring consistency to weaning programs. Other trials have either fed different amounts of MR the last week or weaned calves on a different week for MOD and AGG programs. Another difference was less total MR fed in some of the previous versus the current AGG program. Nonetheless, total HWC were similar at the end of the grower phase for all of these trials. 
Table 5. Apparent digestibility of nutrients and intake of feeds for d 19 to 23 pre-weaning for feeding 2 milk replacer (MR) rates ${ }^{1}$ with and without functional nutrients (NT) to 5 calves per treatment during the 0 to 56 -d nursery phase

\begin{tabular}{|c|c|c|c|c|c|c|c|c|}
\hline Item & \multicolumn{2}{|c|}{ With NT } & \multicolumn{2}{|c|}{ Without NT } & SEM & \multicolumn{3}{|c|}{$P$-value } \\
\hline $\mathrm{CP}$ & 75.0 & 86.5 & 77.0 & 82.9 & 2.82 & 0.78 & 0.003 & 0.33 \\
\hline $\mathrm{DM}$ & 82.2 & 89.5 & 80.8 & 86.9 & 1.54 & 0.02 & 0.001 & 0.71 \\
\hline Fat & 93.6 & 97.4 & 95.5 & 97.6 & 1.83 & 0.56 & 0.11 & 0.65 \\
\hline $\mathrm{OM}$ & 83.4 & 90.3 & 82.1 & 87.9 & 1.44 & 0.02 & 0.001 & 0.72 \\
\hline NDF & 15.2 & 6.5 & 12.9 & 7.4 & 2.51 & 0.04 & 0.01 & 0.53 \\
\hline \multicolumn{9}{|c|}{ DMI, $\mathrm{kg} / \mathrm{d}$} \\
\hline Starter & 0.18 & 0.08 & 0.25 & 0.09 & 0.133 & 0.78 & 0.33 & 0.84 \\
\hline $\mathrm{MR}$ & 0.63 & 1.25 & 0.63 & 1.25 & - & - & - & - \\
\hline Total & 0.81 & 1.33 & 0.87 & 1.34 & 0.133 & 0.78 & 0.001 & 0.84 \\
\hline
\end{tabular}

${ }^{1}$ Moderate (MOD): $0.66 \mathrm{~kg}$ of DM of a $27 \% \mathrm{CP}, 17 \%$ fat MR powder daily fed for $49 \mathrm{~d}$; aggressive (AGG): $0.66 \mathrm{~kg}$ of DM of a $27 \% \mathrm{CP}, 17 \%$ fat MR powder fed for $4 \mathrm{~d}$, then $0.96 \mathrm{~kg}$ of DM for $4 \mathrm{~d}$, then $1.31 \mathrm{~kg}$ of DM fed for $34 \mathrm{~d}$, then $0.66 \mathrm{~kg}$ of DM for $7 \mathrm{~d}$.

Table 6. Apparent digestibility of nutrients and intake of feeds for d 40 to 44 pre-weaning for feeding 2 milk replacer (MR) rates ${ }^{1}$ with and without functional nutrients (NT) to 5 calves per treatment during the 0 to 56 -d nursery phase

\begin{tabular}{|c|c|c|c|c|c|c|c|c|}
\hline Item & \multicolumn{2}{|c|}{ With NT } & \multicolumn{2}{|c|}{ Without NT } & SEM & \multicolumn{3}{|c|}{$P$-value } \\
\hline DM & 85.5 & 87.6 & 82.6 & 82.8 & 1.54 & 0.02 & 0.05 & 0.52 \\
\hline Fat & 89.1 & 95.9 & 91.6 & 92.8 & 1.83 & 0.88 & 0.03 & 0.14 \\
\hline $\mathrm{OM}$ & 86.8 & 88.4 & 84.1 & 84.3 & 1.44 & 0.02 & 0.05 & 0.64 \\
\hline NDF & 27.0 & 14.6 & 17.7 & 9.9 & 2.51 & 0.01 & 0.001 & 0.36 \\
\hline \multicolumn{9}{|c|}{ DMI, $\mathrm{kg} / \mathrm{d}$} \\
\hline Starter & 0.83 & 0.38 & 0.70 & 0.43 & 0.133 & 0.80 & 0.01 & 0.52 \\
\hline MR & 0.63 & 1.26 & 0.63 & 1.26 & - & - & - & - \\
\hline Total & 1.46 & 1.64 & 1.34 & 1.69 & 0.133 & 0.85 & 0.05 & 0.50 \\
\hline
\end{tabular}

${ }^{1}$ Moderate (MOD): $0.66 \mathrm{~kg}$ of DM of a $27 \% \mathrm{CP}, 17 \%$ fat MR powder daily fed for $49 \mathrm{~d}$; aggressive (AGG): $0.66 \mathrm{~kg}$ of DM of a $27 \% \mathrm{CP}, 17 \%$ fat MR powder fed for $4 \mathrm{~d}$, then $0.96 \mathrm{~kg}$ of DM for $4 \mathrm{~d}$, then $1.31 \mathrm{~kg}$ of DM fed for $34 \mathrm{~d}$, then $0.66 \mathrm{~kg}$ of DM for $7 \mathrm{~d}$.

Table 7. Apparent digestibility of nutrients and intake of feeds for d 52 to 56 preweaning for feeding 2 milk replacer (MR) rates ${ }^{1}$ with and without functional nutrients (NT) to 5 calves per treatment during the 0 to 56 -d nursery phase

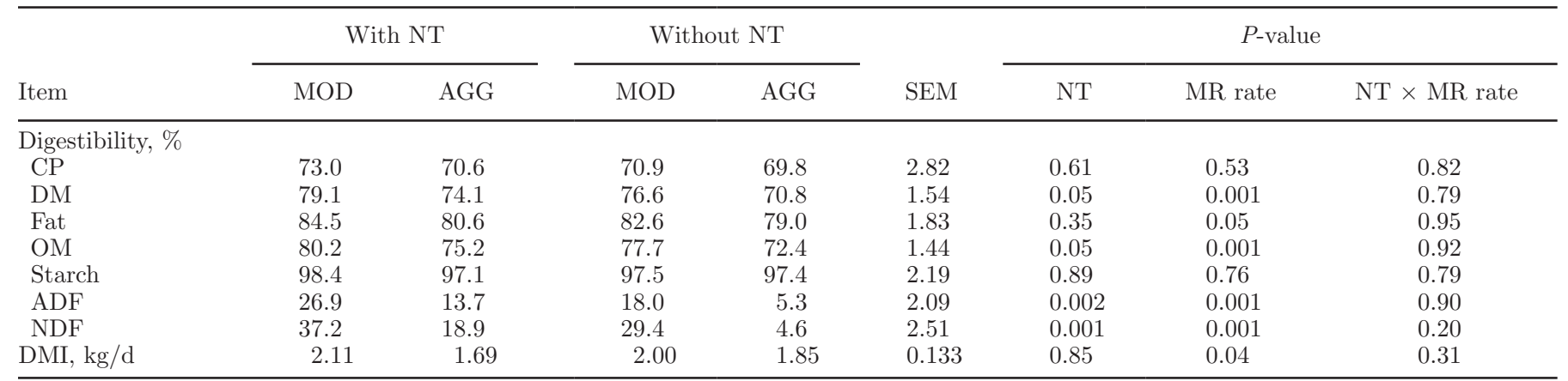

${ }^{1}$ Moderate (MOD): $0.66 \mathrm{~kg}$ of DM of a $27 \% \mathrm{CP}, 17 \%$ fat MR powder daily fed for $49 \mathrm{~d}$; aggressive (AGG): $0.66 \mathrm{~kg}$ of DM of a $27 \% \mathrm{CP}, 17 \%$ fat MR powder fed for $4 \mathrm{~d}$, then $0.96 \mathrm{~kg}$ of DM for $4 \mathrm{~d}$, then $1.31 \mathrm{~kg}$ of DM fed for $34 \mathrm{~d}$, then $0.66 \mathrm{~kg}$ of DM for $7 \mathrm{~d}$. 
In the current trial, calves fed the AGG program had their MR reduced approximately in half for the last 7 $\mathrm{d}$ to $0.66 \mathrm{~kg}$ of DM daily before full weaning. A possible way to avoid less postweaning growth in calves fed AGG versus MOD programs is to reduce the MR rate to approximately $0.7 \mathrm{~kg}$ of $\mathrm{DM}$ for $3 \mathrm{wk}$ before weaning (Hill et al., 2007c, 2012). Weaning by gradually reducing MR fed for approximately 3 wk before weaning (Khan et al., 2007a,b; Sweeney et al., 2010) has also been reported to maintain preweaning ADG from feeding high amounts of MR. This has allowed for more intake of dry feed during that 3 -wk period and maintained growth during the first $3 \mathrm{wk}$ of age when MR feeding rates were greater than $0.7 \mathrm{~kg}$ of $\mathrm{DM}$; this should aid in rumen development and improve postweaning digestion.

Another possible way to avoid less postweaning growth in calves fed AGG versus MOD programs is to feed a MR with a balanced CP-to-ME or CP-to-fat ratio (Hill et al., 2009a,b). The ratio of CP to ME influences both preweaning growth and intake of dry feed. A near optimal ratio in MR was reported to be $25 \%$ to $27 \% \mathrm{CP}$ with AA balance and approximately $17 \%$ fat (Hill et al., 2009a,b).

Whereas feeding an AGG program reduced digestion compared with feeding a MOD program, feeding NT increased the digestibility of many nutrients. Improved digestibility from feeding NT translated into a $13 \%$ improvement in ADG (10.7 kg more) and 16\% improve- ment in HWC (1.4 cm more) over the 112-d trial. This was $10.7 \mathrm{~kg}$ more BW gain and $1.4 \mathrm{~cm}$ more HWC over $112 \mathrm{~d}$. The difference in feeding AGG versus MOD programs was $8.6 \mathrm{~kg}$ more $\mathrm{BW}$ gain and $0.4 \mathrm{~cm}$ less HWC over 112 d. Calves fed MOD with NT gained 97.1 $\mathrm{kg} \mathrm{BW}$ and $11.3 \mathrm{~cm}$ of $\mathrm{HWC}$, whereas calves fed AGG without NT gained $95 \mathrm{~kg}$ of BW and $9.3 \mathrm{~cm}$ of HWC over 112 d. Butyric acid, a component of NT, has been shown to increase digestion in calves (Guilloteau et al., 2009; Górka et al., 2011; Kato et al., 2011). Linolenic acid, another component of NT, has been shown to increase frame growth in calves (Hill et al., 2007a,b, 2009a). Additionally, butyrate has been reported to improve insulin sensitivity (Kato et al., 2011). Insulin insensitivity was an issue in calves fed large amounts of MR in 2 meals daily (Bach et al., 2013), as with AGG, and might also explain why growth slows after 5 wk of age, as observed in the current trial.

\section{CONCLUSIONS}

Digestibility of nutrients increased with age, but digestibility of NDF and ADF was still lower than mature cows at $\mathrm{d} 56$. Digestibility was less in calves fed AGG versus MOD. These increasing digestibility measurements with age reflect that rumen development was increasing with age, it was not completely developed by d 56, and was less in calves fed AGG versus MOD. Calves fed AGG had greater ADG and HWC before 8

Table 8. Performance of calves previously fed 2 milk replacer (MR) rates ${ }^{1}$ with and without functional nutrients (NT) during the 56 to 112 -d grower phase

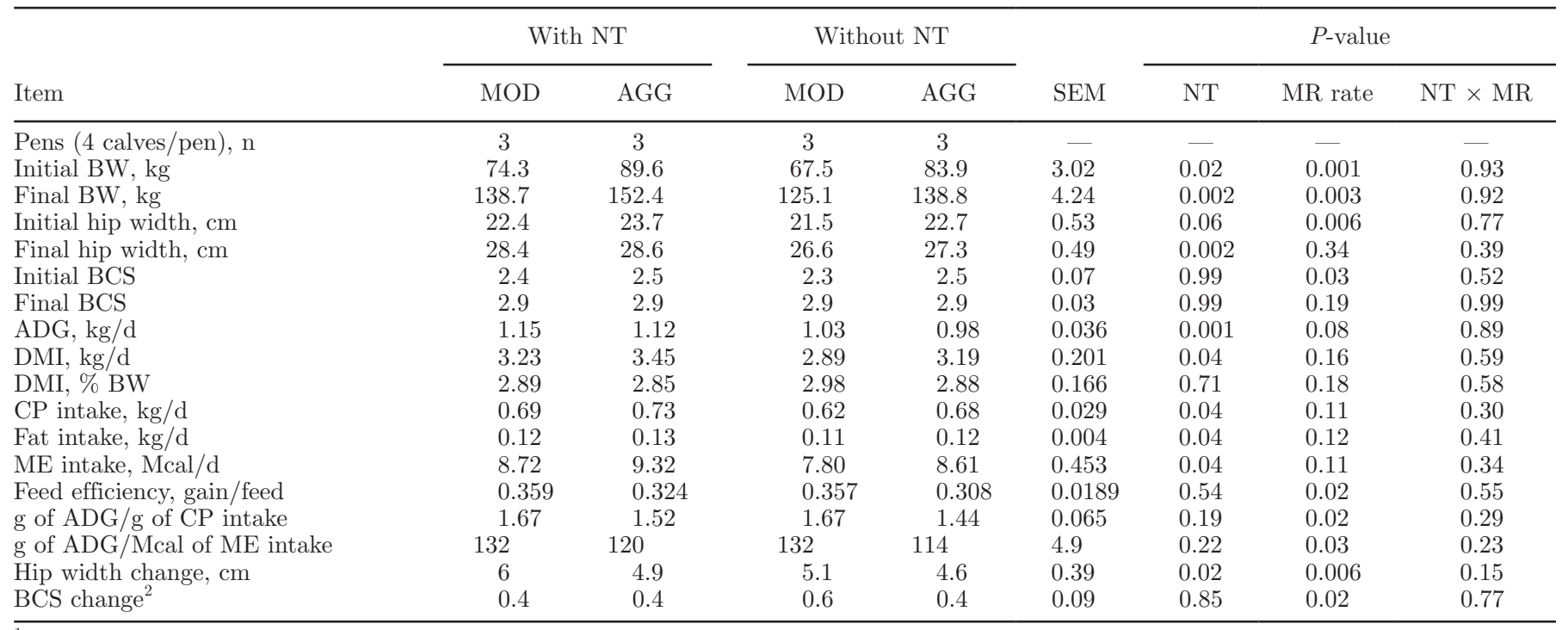

${ }^{1}$ Moderate (MOD): $0.66 \mathrm{~kg}$ of DM of a $27 \% \mathrm{CP}, 17 \%$ fat MR powder daily fed for $49 \mathrm{~d}$; aggressive (AGG): $0.66 \mathrm{~kg}$ of DM of a $27 \% \mathrm{CP}, 17 \%$ fat MR powder fed for $4 \mathrm{~d}$, then $0.96 \mathrm{~kg}$ of DM for $4 \mathrm{~d}$, then $1.31 \mathrm{~kg}$ of DM fed for $34 \mathrm{~d}$, then $0.66 \mathrm{~kg}$ of DM for $7 \mathrm{~d}$.

${ }^{2} 1$ - to 5 -point system, with 1 being thin and 5 being obese. 
wk of age, but lesser ADG and HWC after 6 wk of age compared with calves fed MOD. The lower feed efficiency (ADG per unit intake of DM, CP, and ME) from 8 to 16 wk of age in calves fed AGG is likely reflective of poor digestion of nutrients in calves fed AGG versus MOD. Calves fed NT had greater digestibility of OM, DM, NDF, and ADF compared with calves not fed NT. Calves fed NT had $10.7 \mathrm{~kg}(13 \%)$ more BW gain and $1.4 \mathrm{~cm}(16 \%)$ more HWC over $112 \mathrm{~d}$ compared with calves not fed NT. This was a greater improvement in growth than the difference in AGG and MOD programs over $112 \mathrm{~d}$.

\section{REFERENCES}

AOAC International. 2000. Official Methods of Analysis. Vol. I 17th ed. AOAC International, Arlington, VA.

Bach, A., L. Domingo, C. Montoro, and M. Terre. 2013. Short communication: Insulin responsiveness is affected by the level of milk replacer offered to young calves. J. Dairy Sci. 96:4634-4637.

Bateman, H. G., II, T. M. Hill, J. M. Aldrich, R. L. Schlotterbeck, and J. L. Firkins. 2012. Meta analysis of the impact of initial serum protein concentration and empirical prediction model for growth of neonatal Holstein calves through eight weeks of age. J. Dairy Sci. 95:363-369.

Bernard, J. K., R. C. Delost, F. J. Mueller, J. K. Miller, and W. M. Miller. 1991. Effect of wet or dry corn gluten feed on nutrient digestibility and milk yield and composition. J. Dairy Sci. 74:3913-3919.

Bouchard, R., G. J. Brisson, and J. P. Julien. 1973. Nutritive value of bacterial sludge and whey powders for protein in calf milk replacers and on chromic oxide as indicator of digestibility. J. Dairy Sci. 56:1445-1449.

Cowles, K. E., R. A. White, N. L. Whitehouse, and P. S. Erickson 2006. Growth characteristics of calves fed an intensified milk replacer regime with additional lactoferrin. J. Dairy Sci. 89:48354845

Dubois, M., K. A. Gilles, J. K. Hamilton, P. A. Rebers, and F. Smith 1956. Colorimetric method for determination of sugars and related substances. Anal. Chem. 28:350-356.

Esselburn, K. M., K. M. O'Diam, T. M. Hill, H. G. Bateman, J. M. Aldrich, R. L. Schlotterbeck, and K. M. Daniels. 2013. Intake of specific fatty acids and fat alters growth, health, and titers following vaccination in dairy calves. J. Dairy Sci. 96:5826-5835.

FASS. 2010. Guide for the Care and Use of Agricultural Animals in Research and Teaching. 3rd ed. FASS Inc., Champaign, IL.

Górka, P. Z. M. Kowalski, P. Pietrzak, A. Kotunia, W. Jagusiak, J J. Holst, P. Guillotieau, and R. Zabielski. 2011. Effect of method of delivery of sodium butyrate on rumen development in newborn calves. J. Dairy Sci. 94:5578-5588.

Guilloteau, P., R. Zabielski, J. C. David, J. W. Blum, J. A. Morisset, M. Biernat, J. Wolinski, D. Laubitz, and Y. Hamon. 2009. Sodium butyrate as a growth promoter in milk replacer formula for young calves. J. Dairy Sci. 92:1038-1049.

Hall, M. B. 2009. Analysis of starch, including maltooligosaccharides, in animal feeds: A comparison of methods and a method recommended for AOAC collaborative study. J. AOAC Int. 92:42-49.

Heinrichs, A. J., and B. S. Heinrichs. 2011. A prospective study of calf factors affecting first-lactation and lifetime milk production and age of cows when removed from the herd. J. Dairy Sci. 94:336-341.

Hibbs, J. W., H. R. Conrad, W. D. Pounden, and N. Frank. 1956. A high roughage system for raising calves based on early development of rumen function. VI. Influence of hay to grain ratio on calf performance, rumen development, and certain blood changes. J. Dairy Sci. 39:171-179.

Hill, T. M., J. M. Aldrich, R. L. Schlotterbeck, and H. G. Bateman II. 2007a. Effects of changing the fat and fatty acid composition of milk replacers fed to neonatal calves. Prof. Anim. Sci. 23:135-143.

Hill, T. M., J. M. Aldrich, R. L. Schlotterbeck, and H. G. Bateman II. 2007b. Amino acids, fatty acids, and fat sources for calf milk replacers. Prof. Anim. Sci. 23:401-408.

Hill, T. M., J. M. Aldrich, R. L. Schlotterbeck, and H. G. Bateman II. 2007c. Effects of the feeding rate of high protein calf milk replacers. Prof. Anim. Sci. 23:649-655.

Hill, T. M., H. G. Bateman, J. M. Aldrich, J. M. Quigley, and R. L. Schlotterbeck. 2013. Evaluation of acidified, ad libitum milk replacer programs for dairy calves. J. Dairy Sci. 96:3153-3162.

Hill, T. M., H. G. Bateman II, J. M. Aldrich, and R. L. Schlotterbeck. 2009a. Effects of changing the essential and functional fatty acid intake of dairy calves. J. Dairy Sci. 92:670-676.

Hill, T. M., H. G. Bateman II, J. M. Aldrich, and R. L. Schlotterbeck. 2009b. Optimizing nutrient ratios in milk replacers for calves less than five weeks of age. J. Dairy Sci. 92:3281-3291.

Hill, T. M., H. G. Bateman II, J. M. Aldrich, and R. L. Schlotterbeck. 2010. Effect of milk replacer program on digestion of nutrients in dairy calves. J. Dairy Sci. 93:1105-1115.

Hill, T. M., H. G. Bateman II, J. M. Aldrich, and R. L. Schlotterbeck. 2012. Methods of reducing milk replacer to prepare dairy calves for weaning when large amounts of milk replacer have been fed. Prof. Anim. Sci. 28:332-337.

Hill, T. M., H. G. Bateman II, J. M. Aldrich, R. L. Schlotterbeck, and K. G. Tanan. 2008. Optimal concentrations of lysine, methionine, and threonine in milk replacers for calves less than five weeks of age. J. Dairy Sci. 91:2433-2442.

Hill, T. M., M. J. VandeHaar, L. M. Sordillo, D. R. Catherman, H. G. Bateman II, and R. L. Schlotterbeck. 2011. Fatty acid intake alters growth and immunity of milk-fed calves. J. Dairy Sci. 94:39363948

Jasper, J., and D. M. Weary. 2002. Effects of ad-libitum milk intake on dairy calves. J. Dairy Sci. 85:3054-3058.

Kato, S., K. Sato, H. Chida, S. Roh, S. Ohwada, S. Sato, P. Guilloteau, and K. Katoh. 2011. Effects of Na-butyrate supplementation in milk formula on plasma concentrations of GH and insulin, and on rumen papilla development in calves. J. Endocrinol. 211:241-248.

Kertz, A. F., and H. Chester-Jones. 2004. Invited review: Guidelines for measuring and reporting calf and heifer experimental data. J. Dairy Sci. 87:3577-3580.

Khan, M. A. H. J. Lee, W. S. Lee, H. S. Kim, K. S. Ki, T. Y. Hur, G. H. Suh, S. J. Kang, and Y. J. Choi. 2007b. Structural growth, rumen development, and metabolic and immune responses of Holstein male calves fed milk through step-down and conventional methods. J. Dairy Sci. 90:3376-3387.

Khan, M. A., H. J. Lee, W. S. Lee, H. S. Kim, S. B. Kim, K. S. Ki, J. K. Ha, H. G. Lee, and Y. J. Choi. 2007a. Pre- and postweaning performance of Holstein female calves fed milk through step-down and conventional methods. J. Dairy Sci. 90:876-885.

NRC. 2001. Nutrient Requirements of Dairy Cattle. 7th rev. ed. Natl. Acad. Sci., Washington, DC.

Osorio, J. S., R. L. Wallace, D. J. Tomlinson, T. J. Earleywine, M. T. Socha, and J. K. Drackley. 2012. Effects of source of trace minerals and plane of nutrition on growth and health of transported neonatal dairy calves. J. Dairy Sci. 95:5831-5844.

Robertson, J. B., and P. J. Van Soest. 1981. The Detergent System of Analysis and its Application to Human Foods. Cornell University, Ithaca, NY.

Sayer, K. M., C. D. Buckner, G. E. Erickson, T. J. Klopfenstein, C. N. Macken, and T. W. Loy. 2013. Effect of corn bran and steep inclusion in finishing diets on diet digestibility, cattle performance, and nutrient mass balance. J. Anim. Sci. 91:3847-3858.

Suarez-Mena, F. X., T. M. Hill, A. J. Heinrichs, H. G. Bateman II, J. M. Aldrich, and R. L. Schlotterbeck. 2011. Effects of includ- 
ing corn distillers dried grains with solubles in dairy calf feeds. J. Dairy Sci. 94:3037-3044.

Sweeney, B. C., J. Rushen, D. M. Weary, and A. M. de Passillé. 2010. Duration of weaning, starter intake, and weight gain of dairy calves fed large amounts of milk. J. Dairy Sci. 93:148-152.

Terre, M., M. Devant, and A. Bach. 2007a. Effect of level of milk replacer fed to Holstein calves on performance during the preweaning period and starter digestibility at weaning. Livest. Sci. 110:82-88.

Terre, M., M. Devant, and A. Bach. 2007b. Performance and nitrogen metabolism of calves fed conventionally or following an enhancedgrowth feeding program during the preweaning period. Livest. Sci. 105:109-119.

Van Keulen, J. V., and B. A. Young. 1977. Evaluation of acid insoluble ash as a natural marker in ruminant digestibility studies. J. Anim. Sci. 44:282-287.
Van Soest, P. J., J. B. Robertson, and B. A. Lewis. 1991. Methods for dietary fiber, neutral detergent fiber, non-starch polysaccharides in relation to animal nutrition. Symposium: Carbohydrate methodology, metabolism and nutritional implications in dairy cattle. J. Dairy Sci. 74:3583-3597.

Warner, R. G., W. P. Flatt, and J. K. Loosli. 1956. Dietary factors influencing the development of the animal's stomach. J. Agric. Food Chem. 4:788-792.

Wildman, E. E., G. M. Jones, P. E. Wagner, R. L. Boman, H. F. Trout Jr., and T. N. Lesch. 1982. A dairy cow body condition scoring system and its relationship to selected production characteristics. J. Dairy Sci. 65:495-501. 